\title{
Tantangan Ketenagakerjaan Dan Pengembangan Sumber Daya Di Masa Depan
}

\author{
Oleh : Prijono Tjiptoherijanto
}

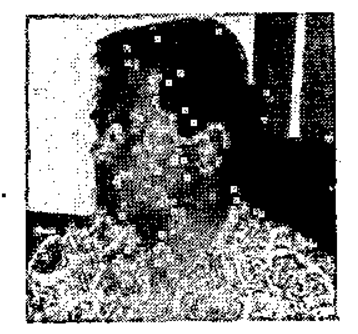

H. Prijono Tjiptoherjanto, lahir 3 April 1958 di Malang, adalah dosen pada Fakultas ekonomi Universi tas Indonesia. Alumnus Fakultas Ekonomi UI (1974). GelarMA diperoleh di University of The Philippines tahun 1977, dan Ph.Dnya diperoleh di University of Hawaii tahun 1981. Selain itu ia juga menjabat sebagai Deputy Ketua Bidang Diklat Il pada Lembaga AdministrasiNegara (LAN) Rl, disamping sebagai.Sekjen PP. ISEEl. Karya tulis yang telah diterbitkan : "Penduduk dan Pembangunan Ekonomi", "Ekonomi Indonesia" dan "Pengembangan SDM"

\section{Pendahuluan}

Tujuan pembentukan negara kesatuan Indonesia seperti tertera pada alinea ke 4 Mukadimah UUD 1945 yang antara lain dinyatakan dalam upaya : (a) memajukan kesejahteraan umum, (b) mencerdaskan kehidupan bangsa dan (c) ikut meláksanakan ketertiban dunia, perlu diwujudkan melalui rangkaian proses pembangunan nasional yang terencana dan berkesinambungan. Olehkarenanya apabila kesejahteraan umum, khususnya yang menyangkut kesejahiteraan material, ingin dan telah diwujudkan pada kurun pertama pembangunanjangka panjang 25 tahun yang berakhir pada Pelita $V$, maka kesejahteraan non-material yang juga mengandung di dalamnyamencerdaskankehidupanbangsa, perlu terwujud dalam rangkaian pembangunan jangka panjang yang kedua. Upaya yang dilakukan selama. 25 tahun pertama pembangunan nasional, dititik beratkan pada pembangunan ekonomi untuk mempersiapkan kerangka landasan bagi proses pembangunan yang berkelanjutan. Sebagai konsekwensi dari titik berat ini, maka upaya untuk meningkatkan ekonomi dan kesejahteraan rakyat menjadi prioritas utama dan dilakukan melalui serangkaian kegiatan dan kebijaksanaan yang lebih condong mengatur perekonomian negara dengan memperhatikan perkembangan ekonomi di negara-negara tetangga khususnya dan perekonomian internasional pada umumnya. Pengamatan yang mendalam tersebut menghasilkan suatu keyakinan bahwa upaya perbaikan dan peningkatan perekonomian yang bertumpu pada 
Pertanyaan-pertanyaan yang mengarah pada kesiapan seorang lulusan dalam menghadapi dunia kerja, merupakan indikator untuk mengukur relevansi ini. Sementaraitu kesesuaian antara pendidikan yang telah ditamatkan dengan jenis pekerjaan yang dipegang, juga mengungkapkan masalah relevansi.

\section{Aspek Kesehatan}

Pengembàngan sumber daya manusia menjadi penting diperhatikan karena masalah kependudukan yang belum sepenuhnya bisa diatasi. Sementara itu, keadaan ekonomi yang masih belum menentu dan kecenderungan investasi yang lebih padat teknologi, menambah berat persoalan yang telah ada. Dengan jumlah pengangguran terbuka yang tidak kecil, daya beli masyarakat belum bisa sepenuhnya ditingkatkan. Keadaan semacam ini bisa menjurus kearah "keresahan sosial" yang sulit diredam, bila tidak ditangani sejak dini.

Dalam situasi dimana penawaran tenagakerja lebih besar dari padalowongan yang tersedia, hanya tenaga kerja yang memiliki ketrampilan yang punya kesempatan untuk masuk ke pasaran kerja. Dengan demikian keterampilan pekerja harus ditingkatkan agar tenaga kerja ini dapat masuk ke lapangan kerja. Sementara itu, keadaan ekonomi yang kurang baik serta kecenderungan investasi yang lebih mengarah pada padat teknologi, semakin memperburuk keadaan ketenagakerajaan yang dihadapi.

Dalam hubungan dengan masalah tersebut, penyediaan jumlah dan mutu pekerjaan yang memadai merupakan usaha yañg amat serius dalam menciptakan lapangan pekerjaan. Namun, usaha peningkatan mutu pekerja biasanya berkaitan pula dengan masalah pendidikan, kesehatan dan keamanan yang merupakan tanggungjawab bersama seluruh anggota masyarakat.

Dilihat dari sisi derajat kesehatan masyarakat, proses pembangunan yang dilaksanakan selama ini telah membawa therising demandsdalam masyarakat luas. Permintaan-permintaan baru bermunculan, sementara permintaan lama semakin meningkat bila dipandang dari segi mutunya. Masyarakat semakin menuntut pelayanan kesehatan yang cepat, tepat dan berhasil guna. Namun perlu disadari, bahwa sebagian besar masyarakat yang. memerlukan jasa-jasa pelayanan kesehatan tersebut masih tergolong berpenghasilan rendah. Oleh karenanya, kalau pelayanan kesehatan yang canggih tersebut memerlukan pembiayaan cukup besar, maka jasa-jasa ini akan sulit dinikmatimasyarakat luas. Hanya segolongan masyarakattertentu yang bisa mendapatkan pelayanan "Prima" itu. Walaupun Puskesmas dan Posyandu telah tumbuh dimana-mana dan șiap melayani kebutuhan masyarakat, tetapi yang penting adalah sejauh mana accessability masyarakat terhadappelayanan kesehatan yang tersedia itu. Ini menyangkut jarak, waktu dan juga biaya. Tidak akan ada gunanya banyak didirikan fasilitas kesehatan namun jangkauannya baik dalam jarak waktu dan biaya belum bisamencapai masyarakat yang memerlukannya. Dalam bahasa teknis, bukan jumlah fasilitasnya yang menjadi perhatian utama, namun penggunaan (utilization) atas fasilitas tersebut yang mendapat perhatian secara seksama. Kesulitan penelitian yang dihadapi dalam melakukan penilaian atas barang-barang 
masyarakat seperti jasa kesehatan dan pendidikąn misalnya, adalah adanya economic of scale yang perlu diperhatikan.

Pendirian dan penambahan Puskesmas atau Posyandu untuk wilayah tertentu perlu dibandingkan dengan luas pelayanan bagi pusat-pusat pelayanan serupa. Pendirian tempat-tempat pendidikan tertentu, perlu dibandingkan dengan pendirian jasa-jasa yang serupa. Upaya untuk mengantisipasi economic of scale ini tentunya berhubungan pula dengan consumer surplus yang bisa dinikmati oleh seluruh konsumen jasa kesehatan dan pendidikan. Jangan terjádi banyak consumersurplus darikelompok tertentu tersita hanya karena kesalahan dalam menentukan prioritas.

Sebagai dampak dari adanya keinginan untuk menjaga kepuasan konsumen, maka tidak jarang untuk jenisjènis public goods yang tidak terlalu ber̀sifat non-excludability dikenakan 'price discrimination. Perbedaan harga semacam ini banyak diberlakukan pada public utilities yang dikelola Pemerintah. Sudah barang tentu tujuannya adalah pemerataan. Namun ada juga pembedaan harga yang dikenakan atas jasa pelayanan kesehatan dan pendidikan yang dilakukan oleh pihakpihak non-pemerintah. Dalam hubungan ini tentunya pertimbangan market segmentation yang lebih banyak berperan. Namun, untuk melakukan tindakantindakan semacam itu perlu suatu pengkajian dan penelitian pasaryangcukup mendalam. Oleh karenanya, upaya pengembangan sumber daya manusia, yang antara lain ditempuh melalui pengingkatan derajat kesehatan dan jenjang pendidikan juga perlu dilakukan secara terarah dan berhati-hati.

\section{Pasar Kerja}

Sementaraitu,merupakan kenyataan yang harus diterima bahwa telah terjadi ketimpangan dalam pasar tenaga kerja dewasa ini.

Pertama, adalah ketidakseimbangan secara umum, yaitu jumlah tenaga kerja yang ada melebihi jumlah lapangan yang tersedia. Meskipun demikian, secara struktural dan sektor masih terdapat kesenjangan antara keterampilan yang diperlukan dibandingkan dengan keterampilan yang tersedia. Kesenjangan ini menyebabkan kesan ketidakseimbangan secara umum tersebut menjadi berkurang maknanya.

Dimensi lain dari ketidakseimbangan ketenagakerjaan menyangkut mutu tenaga kerja. Tuntutan akan tenaga kerja yang berketerampilan semakin meningkatbukan saja untuk memenuhi kebutuhan pembangunan, tetapi: juga untuk meningkatkan produktivitas dan sebagai upaya mengurangi kemiskinan sekaligus . mengangkat status tenaga kerja. Dalam hubungan ini maka tampak bahwa upaya perlindungan pekerja menjadi hal yang perlu diperhatikan, terutama dalam hubungan dengan perusahaan.

Apabila dilihat lebih jauh hubungan antara permasalahan yang dihadapi di bidang ketenagakerjaan, khususnys yang menyangkut "setengah menganggur", dengan proses industrialisasi yang berlaku dalam tahap pembangunan nasional saat ini, tampaknya sektor industri menawarkan suatu "hari depan" yang lebih baik. Terutama bila dilihat dari perkembangan kesempatankerja yang terjadi selama tahuntahun terakhirini seperti ditunjukkan dalam Tabel 1. 
tabel 1 : Elastisitas Kesempatan Kerja

\begin{tabular}{llrr}
\hline & & \multicolumn{2}{c}{ Periode } \\
\cline { 3 - 4 } No. & Sektor Ekonomi & $1980-1985$ & $1985-1988$ \\
\hline 1. & Pertanian & 0,7712 & 0,5899 \\
2. & Industri & 0,0245 & 0,5285 \\
3. & Pertambangan & 1,2519 & 1,9990 \\
4. & Listrik/Gas/Air & 0,6853 & 0,2807 \\
5. & Bangunan & 2,1286 & 0,5606 \\
$6 . \quad$ Perdagangan & 1,5927 & 1,1244 \\
7. & Pengangkutan & 1,0917 & 0,6166 \\
8. & Lembaga Keuangan & 0,4959 & 0,4215 \\
9. & Jasa-jasa lainnya & 0,8362 & 0,9591 \\
\hline Seluruh Sektor & 0,9091 & 0,7699 \\
\hline
\end{tabular}

Sumber : Depnaker, Profil Sumber Daya Manusia, 1989/90.

Dari tabel di atas terlihat berkurangnya kesempatan kerja di sektor pertanian yang ditunjukkan dengan penurunan elastisitasnya dari 0,77 menjadi 0,59 . Sedangkan untuk sektor industri bahkan meningkat dari 0,02 menjadi 0,53. Sektor lain yang meningkat dengan cukup drastis terdapat pada sektor pertambangan yaitu dari sebesar -1,25 menjadi 1,99 dan sektorpengangkutan dari 0,09 menjadi 0,62 dalam kurun waktu 1980-1988.

Selain peningkatan dalam kesempatan kerja yang ada, tampaknya sektorindustri juga menjanjikan kehidupan yang lebih baik. Peningkatan upah mini- mum yang terjadi pada sektor-sektor perekonomian dalam beberapa tahun terakhirini. Dari gambaryang tertera dalam Tabel 2, untuk tahun 1981 sektor industri menduduki peringgkat pertama dari segi besarnya upah minimum. Hal ini berlangsung sampai dengan tahun 1985. Baru pada tahun 1987 upah minimum tertinggi terdapat pada sektor Perdagangan dan Bank. Industri menempati urutan kedua. Agaknya deregullasi sektor moneter dan perbankan yang dilakukan Pemerintah,juga memberikan dampak positif pada pengupahan dan penggajian para pekerja di sektor ini.

Tabel 2

Upah Minimum Menurut Lapangan Usaha per Bulan (dalam ribuan rupiah)

\begin{tabular}{|c|c|c|c|c|c|}
\hline Nó. & $s \in k t \circ r$ & 1981 & 1983 & 1985 & 1987 \\
\hline $\begin{array}{l}1 . \\
2 . \\
3 . \\
4 . \\
5 . \\
6 . \\
7 . \\
8 .\end{array}$ & $\begin{array}{l}\text { Pertanian } \\
\text { Pertambangan } \\
\text { Industri } \\
\text { Listirik/Gas/Air } \\
\text { Bangunan } \\
\text { Perdagangan dan Bank } \\
\text { Pengangkutan } \\
\text { Jasa-jasa }\end{array}$ & $\begin{array}{l}21,9 \\
64,5 \\
46,3 \\
27,3 \\
29,9 \\
53,2 \\
50,5 \\
39,4\end{array}$ & $\begin{array}{l}27,2 \\
72,5 \\
65,6 \\
40,1 \\
36,7 \\
67,3 \\
69,5 \\
54,5\end{array}$ & $\begin{array}{l}38,7 \\
95,9 \\
83,3 \\
60,9 \\
53,1 \\
90,1 \\
85,7 \\
71,6\end{array}$ & $\begin{array}{r}48,4 \\
146,0 \\
98,6 \\
80,6 \\
96,4 \\
159,1 \\
115,5 \\
71,6\end{array}$ \\
\hline
\end{tabular}

Sumber: Departemen Tenaga Kerja, Sub. Dit. Pengupahan, 1987. 


\section{Penutup}

Upaya pengembangan kualitas > sumber daya manusia yang menjadi salah satu alternatif peningkatan kualitas masyarakat Indonesia. harus diselaraskan dengan program-program pembangunan lainnya, sehingga dapat mencapai tujuan yang dicita-citakan. Hanya dengan keterpaduan tersebutsumberdaya manusia yang ada dapat didayagunakan sebagai modal bagi pembangunan. Keterpaduan ini mencakup pula bidang kesehatan, gizi, pendidikan dan latihan serta penyediaan lapangan kerja.

Dengan demikian, usaha peningkatan kualitas sumber daya manusia dapat dilakukan melalui tiga jalur strategik sasaran, yaitu :

a. Usaha perbaikan gizi dan kesehatan masyarakat. b. Peningkatan pendidikan dalam arti luas, serta

c. Meningkatkan partisipasi penduduk dalam pekerjaan (labor participation ratio) dan mengurangi tingkat ketergantungan penduduk non-produktif kepada penduduk yang produktif (dependency ratio).

Upaya tersebut mengisyaratkan perlunya kecukupan gizi dan derajat kesehatan yang memadai bagi penduduk dan dipadukan dengan tersedianya pendidikanyangterarah sertalapangan kerja yang produktif guna menopang upaya peningkatan produktivitas untuk mencapai pertumbuhan ekonomi nasional yang diinginkan. Dengan demikian, perjalanan pembangunan nasional tetap dapat diteruskan untuk mewujudkan masyarakat yang adil, makmur dan sejahtera. 